Gut, 1986, 27, 374-381

\title{
Quantitative and qualitative comparison of gall bladder mucus glycoprotein from patients with and without gall stones
}

\author{
P R C HARVEY, C A RUPAR, S GALLINGER, C N PETRUNKA, AND S M \\ STRASBERG
}

From the Department of Surgery, Mount Sinai Hospital, University of Toronto, Toronto, Ontario, Canada and Department of Biochemistry, The Children's Psychiatric Research Institue, University of Western Ontario, London, Ontario, Canada

SUMMARY Human gall bladder mucus glycoprotein was isolated by Sepharose 4B gel filtration followed by caesium chloride density gradient ultracentrifugation from four groups: patients with cholesterol gall stones, patients with pigmented stones, patients with complete obstruction of the cystic duct and patients with no biliary tract abnormalities (controls). Mucus glycoprotein concentrations in cholesterol gall stone bile $(203 \mu \mathrm{g} / \mathrm{ml} \pm 199 \mathrm{SD}, \mathrm{n}=17)$, pigment gall stone bile $(110 \mu \mathrm{g} / \mathrm{ml} \pm 77 \mathrm{SD}, \mathrm{n}=6)$ and control gall bladder bile $(96 \mu \mathrm{g} / \mathrm{ml} \pm 98 \mathrm{SD}, \mathrm{n}=11)$ were not significantly different. While bile from patients with complete obstruction of the cystic duct contained significantly higher concentrations of mucus glycoprotein $(6220 \mu \mathrm{g} / \mathrm{ml} \pm 4130, \mathrm{n}=4)$. In vitro cholesterol nucleation time was not correlated to gall bladder mucus glycoprotein concentrations. Qualitative analysis of the carbohydrate and amino acid composition showed a basic structure typical of mucus glycoproteins in general. It is unlikely that either quantitative or qualitative differences in mucus glycoproteins are responsible for the rapid in vitro nucleation time characteristic of cholesterol gall stone patients.

Supersaturated bile is necessary for stone formation ${ }^{1}$ but cholesterol supersaturation is a frequent finding in normal gall bladder bile. ${ }^{2-5}$ Evidence that a nucleating defect is also present in the gall bladder bile of patients with cholelithiasis has recently been obtained by several investigators. ${ }^{2-7}$ Mucus glycoprotein might be the nucleating factor. Gall stones have a mucopolysaccharide matrix, ${ }^{8-10}$ hypersecretion of mucus glycoprotein from the gall bladder occurs before stone formation in experimentally induced cholelithiasis in animal models ${ }^{11-14}$ and inhibition of gall bladder mucus glycoprotein secretion by aspirin prevents stones. ${ }^{15}$ Human gall bladder mucus glycoprotein accelerates nucleation in model bile ${ }^{16}$ and bile obtained from prairie dogs. ${ }^{14}$

The purpose of the present study is to determine whether there is a quantitative or qualitative difference in the mucus glycoprotein secreted by the gall

Address for correspondence: Professor S M Strasherg. Department of Surgery, Mount Sinai Hospital, Suite 1142, $6(0)$ University Avenue. Toronto. Ontario M5G 1 X5. Canada.

Received for publication 16 August 1985. bladder of patients with cholesterol cholelithiasis, which might support the preceding observations. Earlier studies measuring mucus glycoprotein used indirect techniques and produced conflicting results. ${ }^{7}{ }^{17} 18$ One of the difficulties in such studies has been to obtain representative and comparable bile samples. Studies to characterise gall bladder mucus glycoprotein have been limited because of the difficulty in obtaining human bile samples. Often bile has to be obtained at necropsy or by Ttube drainage. ${ }^{17-22}$ Once bile is obtained, the isolation of pure mucus glycoprotein has been difficult. Proteolytic digestion and organic extractions have been used ${ }^{19-22}$ which might cause degradation of native mucus glycoprotein into glycoprotein subunits. Techniques to isolate intact mucus glycoprotein have been developed ${ }^{23}$ and applied to purifying undegraded gall bladder mucus glycoprotein. ${ }^{24}$ Only three patients with mixed type gall stones were studied. Few studies have compared the composition of gall bladder mucus glycoprotein from normal controls with that of patients with cholelithiasis. 
The present investigation, using non-degradative procedures, quantifies, and characterises native biliary mucus glycoprotein isolated from four different patient groups; patients with cholesterol gall stones, patients with pigmented stones, patients with complete obstruction of the cystic duct whose gall bladder contained white bile, and patients without biliary tract disease.

\section{Methods}

PATIENTS

Gall bladder bile was obtained from 27 patients undergoing elective cholecystectomy for cholelithiasis. Bile collection methods were approved by the Human Experimentation Committee of the University of Toronto. Patients were given detailed information regarding technique before consenting to take part in the study. All patients had normal liver function tests. The gall bladder was functioning as defined by the presence of typical dark green bile and a total lipid concentration greater than $5 \mathrm{~g} / \mathrm{dl}^{5}$ in 23 of the 27 patients with cholelithiasis. Four patients had obstructed gall bladders. Gall bladder bile from these four patients was characteristic 'white bile' which is a colourless bilirubin-free fluid with a low total lipid content.

Patients with functioning gall bladders were divided into two groups: those with cholesterol stones $(n=17)$ and those with pigmented stones $(n=6)$. The type of stone was determined by inspection and by chemical analysis for cholesterol. ${ }^{25}$ All stones designated cholesterol gall stones were greater than $70 \%$ cholesterol by weight. Pigment stones were black, amorphous, friable, and less than $10 \%$ cholesterol by weight. The patients with obstructed gall bladders all had cholesterol gall stones.

Gall bladder bile was also collected from 11 patients requiring a laparotomy for problems not related to the biliary tract. This group of patients defined as normal controls were having surgery for obesity, duodenal ulcer, Crohn's disease, or colonic cancer. Ultrasound studies of the gall bladder and bile ducts were normal in these patients and the gall bladder appeared normal at surgery.

BILE COLLECTION AND EXTRACTION OF MUCUS The gall bladder was completely aspirated of bile by syringe and needle before any surgical manipulation. Each sample was processed separately, immediately after collection and mucus glycoprotein isolated using the method of Pearson et $\mathrm{al}^{24}$ with Sepharose 4B gel chromatography followed by caesium chloride density gradient ultracentrifugation. Briefly, phenylmethylsulfonyl fluoride (PMSF)
$1.0 \mathrm{mg}$ was added immediately to bile samples $(5 \cdot 0-7 \cdot 0 \mathrm{ml})$ to give a final concentration of $0.82 \mathrm{mM}-1.15 \mathrm{mM}$ of PMSF. Bile was dialysed at $4^{\circ} \mathrm{C}$ against distilled water containing $(0 \cdot() 2 \%$ sodium azide for 72 hours. Dialysed bile was concentrated by lyophilisation and reconstituted with phosphate buffered saline containing $(0 \cdot() 2 \%$ sodium azide (10 $\mathrm{mM}$ phosphate buffer/().2 M $\left.\mathrm{NaCl} /() \cdot() 2 \% \quad \mathrm{NaN}_{3} ; \mathrm{pH} 7 \cdot 4\right)$.

The reconstituted bile solutions were homogenised for 1.0 minute (Stirrer type RzRl-64, Canlab), centrifuged at $4^{\circ} \mathrm{C}$ for 30 minutes at $100000 \mathrm{~g}$ to remove undissolved lipids and the lipid pellet was discarded. The supernatant was chromatographed on a Sepharose $4 \mathrm{~B}$ column $(85 \times 2.5 \mathrm{~cm})$ eluted with the phosphate buffered saline at a flow rate of $120 \mathrm{ml} /$ hour. The void volume fractions as determined by dextran blue were pooled and concentrated by lyophilisation.

The excluded glycoprotein peak from Sepharose 4B chromatography was further purified by caesium chloride density gradient ultracentrifugation ${ }^{23}$ in a Beckman L5-65 preparative ultracentrifuge with a SW 41 Ti rotor. Dry caesium chloride was added to the reconstituted void volume fractions to give a final concentration of $60 \%$. Centrifugation was carried out at $4^{\circ} \mathrm{C}$ at $150000 \mathrm{~g}$ for 48 hours. One millilitre fractions aspirated from the top of the gradient were analysed for protein and carbohydrate as described under analytical methods. Densities were determined by weighing a $500 \mu \mathrm{l}$ aliquot of each fraction.

ANALYTICAL METHODS

Sepharose 4B chromatographic column effluents were screened for protein using the Coomassie Blue binding reaction (Bio-Rad protein assay). ${ }^{26}$ After caesium chloride density gradient protein was estimated by measuring absorbance at $280 \mathrm{~nm}$. Glycoprotein was measured by the method of Mantle and Allen ${ }^{27}$ using pig gastric mucin as standard. This is a modified periodic acid/Schiff method which is practical for estimating glycoproteins in a large number of samples. Mucus glycoprotein in bile was quantified following caesium chloride density gradients correcting for losses as estimated by the addition of purified gall bladder mucus to separate aliquots of bile.

Bile pigments were measured by absorbance at $420 \mathrm{~nm}$. Slab sodium dodecyl sulphate polyacrylamide gel electrophoresis (SDS-PAGE) was done in $10 \%$ gels with a $3 \%$ stacking gel according to the method of Laemmli. ${ }^{28}$ After electrophoresis gels were stained for glycoproteins by the periodate/ Schiff method ${ }^{29}$ and for protein by the Bio-Rad silver staining procedure. ${ }^{30}$ 
The nucleation time defined as the time required for microscopic cholesterol crystals to appear in a bile sample which has been initially cleared of crystals was determined using a standard technique,${ }^{5}$ which is a modification of the method Holan and Holzbach. ${ }^{3}$

Cholesterol was measured by GLC $^{25}$ phospholipid by the method of Bartlett ${ }^{31}$ and bile salts by the 3-hydroxysteroid dehydrogenase technique. ${ }^{32}$ Cholesterol saturation of bile samples was expressed as the cholesterol saturation index. ${ }^{33}$

Mucus glycoprotein amino acids were quantified on a Durrum amino acid analyser after hydrolysis for 16 hours in $6 \mathrm{~N}$ constant boiling $\mathrm{HCl}$. The Beckman lithium citrate three buffer elution system was used with ninhydrin detection and norleucine as an internal standard. In this system glucosamine elutes beween alanine and valine and galactosamine elutes between valine and leucine. The large galactosamine peak interfered with the quantifica- tion of valine, cystine, methionine, and isoleucine. Separation and quantitation of these amino acids from galactosamine was accomplished in separate analyses by extending the length of buffer one elution to include the neutral amino acids.

Carbohydrates were analysed on a HewlettPackard $5710 \mathrm{~A}$ gas liquid chromatograph using a $3 \%$ SE-30 column as trimethyl silyl ethers of methyl glycosides obtained by hydrolysis at $80^{\circ}$ for 16 hours in $1.0 \mathrm{~N}$ methanolic $\mathrm{HCl}$ essentially as described by Laine et al. ${ }^{34}$ Mannitol was used as an internal standard for quantification.

\section{Results}

Sepharose 4B chromatography of white bile separated biliary proteins into an excluded strongly positive PAS glycoprotein fraction and a heterogeneous included protein fraction of lower molecular weight (Fig. 1). White bile has the unique feature

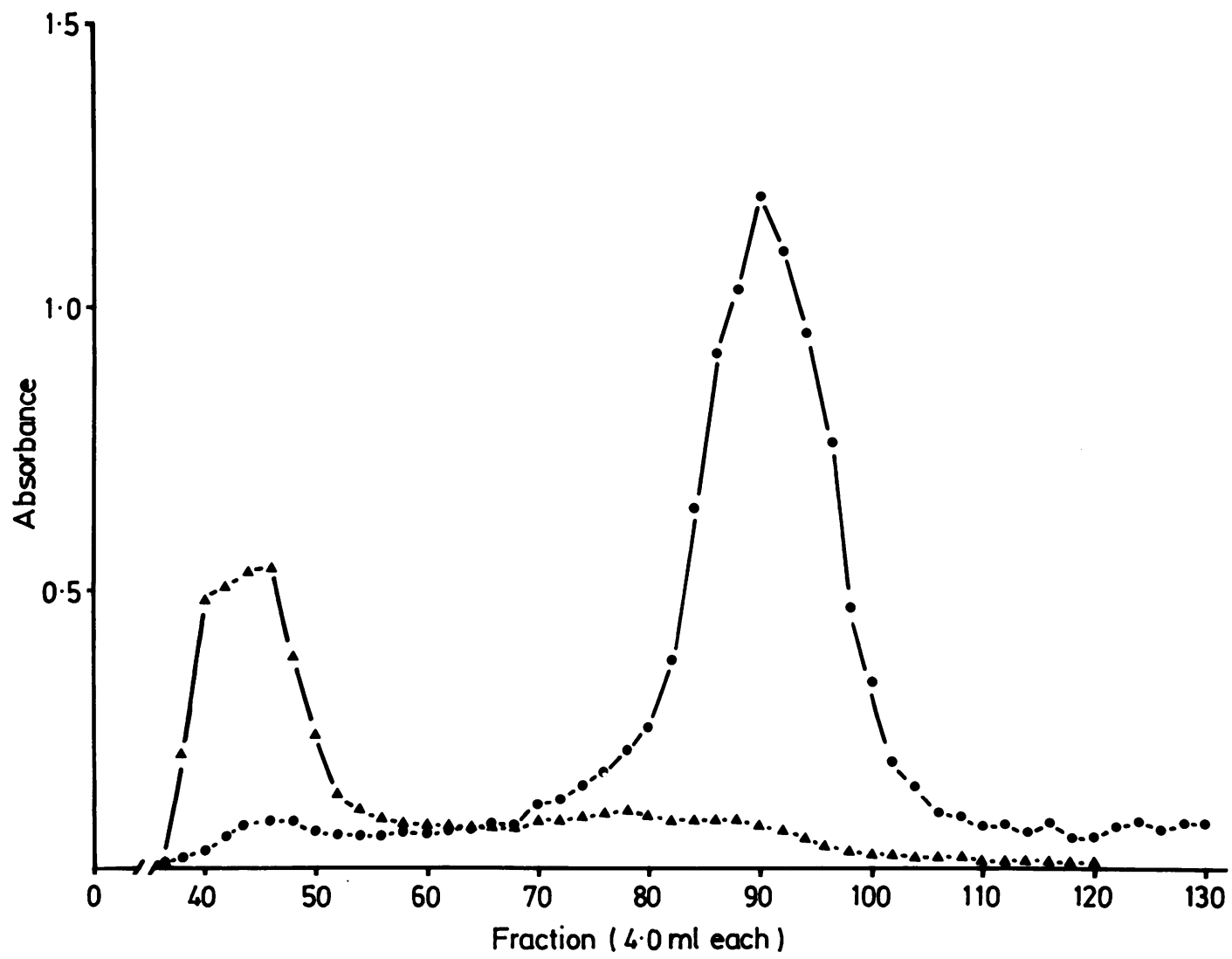

Fig. 1 Sepharose 4B gel filtration chromatography of human white gall bladder bile. Fractions were assayed for protein - by Bio Rad protein assay and for glycoprotein by the periodic acid/Schiff assay. - $\Delta-$ Note that the excluded protein peak showed a very strong $P A S$ reaction whereas the very large included peak had a very weak $P A S$ reaction. 
of being free of bile pigments and lipids that would interfere with the protein analysis. Sepharose 4B chromatography of bile from an unobstructed gall bladder resulted in a pigment peak which overlapped the included protein peak. This bile pigment peak interferes very strongly with the periodic acid/Schiff assay for glycoproteins. Previous investigators have also encountered this difficulty with the included protein peak. ${ }^{24}$ Minor interference was also encountered for the Coomassie blue binding assay for proteins.

The pooled void volume glycoprotein peak from Sepharose 4B chromatography of unobstructed gall bladder bile contained contaminants of lower molecular weight proteins as shown by SDS-PAGE. Traces of biliary pigment as observed by visual inspection, phospholipids and cholesterol as determined by lipid analysis were also present in Sepharose 4B pooled void volume fractions. These contaminants were removed from mucus glycoprotein by $\mathrm{CsCl}$ density gradient ultracentrifugation (Fig. 2). Visual inspection revealed a greenish low density fraction that floated on top of the $\mathrm{CsCl}$ density gradient. Lipid analysis and SDS-PAGE of a clear colourless glycoprotein peak of high density following $\mathrm{CsCl}$ density gradient confirmed that low molecular weight contaminants were removed.

Mucus glycoprotein concentrations in the three bile sample groups: normal bile, cholesterol gall stone bile and pigment gall stone bile are shown in Figure 3. Recovery of added mucus glycoprotein was $83 \% \pm 9 \cdot 5(n=4)$. Mucus glycoprotein concentrations in normal gall bladder bile $(96 \mathrm{ug} / \mathrm{ml} \pm 98 \mathrm{SD}$, $\mathrm{n}=11)$ cholesterol gall stone bile $(203 \mathrm{ug} / \mathrm{ml} \pm 199 \mathrm{SD}$, $\mathrm{n}=17)$ and pigment gall stone bile $(110 \mathrm{ug} / \mathrm{ml} \pm 77 \mathrm{SD}$,

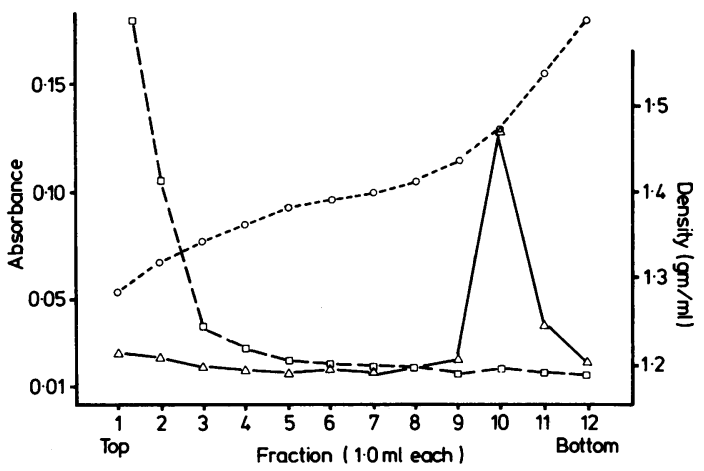

Fig. 2 Caesium chloride density gradient of pooled void volume from Sepharose $4 B$ gel filtration. One millilitre fractions were assayed for glycoprotein by periodic acid/Schiff assay $-\triangle-$, protein by absorbance at $280 \mathrm{~nm}$ $-\square-$, and density by weight of fractions $-\mathrm{O}$.

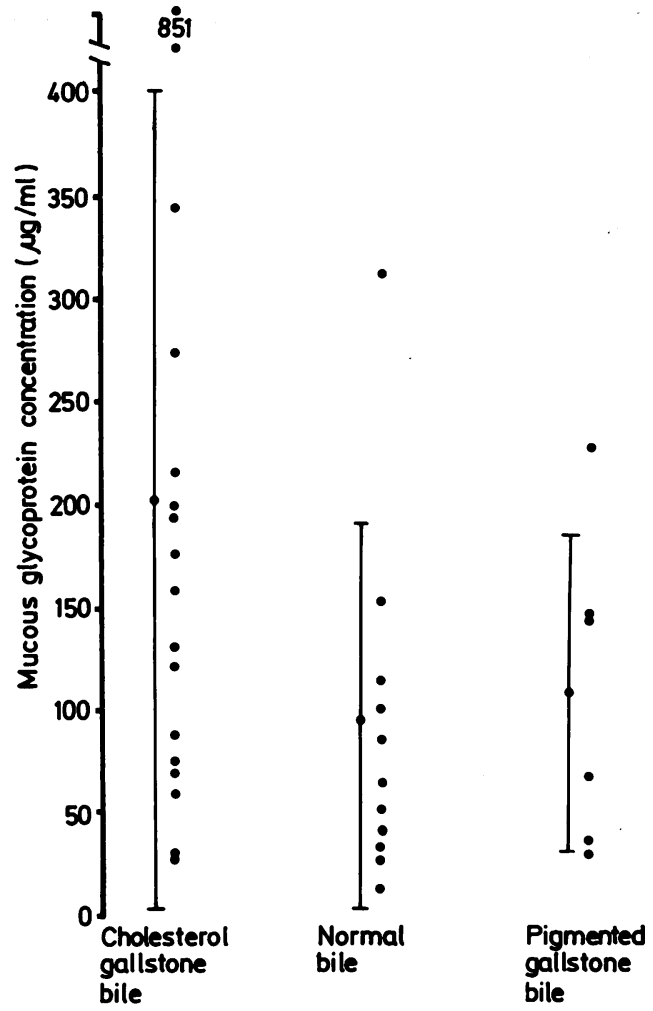

Fig. 3 Human mucus glycoprotein concentrations in three bile sample groups: cholesterol gall stone bile $(203 \mu \mathrm{g} / \mathrm{ml} \pm 199 S D, n=17)$, normal gall bladder bile $(96 \mu \mathrm{g} / \mathrm{ml} \pm 98 S D, n=11)$, and pigment gall stone bile $(110 \mu \mathrm{g} / \mathrm{ml} \pm 77 S D, n=6)$.

$\mathrm{n}=6$ ) were not significantly different (Students $t$ test) and there was a large overlap among the values in the three groups. White bile samples contained significantly higher concentrations of mucus glycoproteins $(6220 \mathrm{ug} / \mathrm{ml} \pm 4130, \mathrm{n}=4)$. Gall bladder mucus glycoprotein concentration, total lipid concentration, cholesterol saturation index and nucleation time of individual gall bladder biles are given in Table 1.

Human biliary mucus glycoprotein has a carbohydrate and amino acid composition typical of mucus glycoprotein in general (Table 2). ${ }^{35}$ Carbohydrates accounted for $79 \%$ (molar basis) whereas amino acids accounted for $21 \%$ of the glycoprotein.

The major sugar moieties fucose, galactose, $\mathrm{N}$-acetylglucosamine and $\mathrm{N}$-acetylgalactosamine characteristic of other mucus glycoproteins, together made up $95 \%$ of the carbohydrates. Minor 
Table 1 Mucus glycoprotein concentration, total lipid concentration, cholesterol saturation index and nucleation time of gall bladder bile

\begin{tabular}{|c|c|c|c|c|}
\hline Patients & $\begin{array}{l}\text { Mucus glycoprotein } \\
\text { concentration }(\mu \mathrm{g} / \mathrm{ml})\end{array}$ & $\begin{array}{l}\text { Total lipids } \\
(\mathrm{g} / \mathrm{dl})\end{array}$ & $\begin{array}{l}\text { Cholesterol } \\
\text { saturation index }\end{array}$ & $\begin{array}{l}\text { Nucleation } \\
\text { Time } \\
\text { (days) }\end{array}$ \\
\hline \multicolumn{5}{|c|}{ Cholesterol stone bile } \\
\hline $\mathrm{KU}$ & 195 & $10 \cdot 74$ & $1 \cdot 19$ & 1 \\
\hline $\mathrm{BE}$ & 159 & 8.91 & 1.02 & 1 \\
\hline $\mathrm{CO}$ & 132 & $10 \cdot 41$ & 0.91 & 1 \\
\hline $\mathrm{CH}$ & 89 & $13 \cdot 38$ & 1.26 & 1 \\
\hline $\mathrm{AR}$ & 71 & $15 \cdot 55$ & $1 \cdot 32$ & 1 \\
\hline WI & 123 & $16 \cdot 39$ & $1 \cdot 18$ & 4 \\
\hline $\mathrm{PH}$ & 423 & 5.59 & 0.97 & 1 \\
\hline LA & 345 & $10 \cdot 58$ & $1 \cdot 11$ & 1 \\
\hline PA & 178 & 13.93 & $1 \cdot 04$ & 1 \\
\hline FR & 851 & $12 \cdot 83$ & 0.92 & 1 \\
\hline $\mathrm{HE}$ & 77 & $13 \cdot 07$ & 1.45 & 2 \\
\hline SQ & 31 & 8.77 & $1 \cdot 13$ & 3 \\
\hline $\mathrm{BE}$ & 217 & $14 \cdot 22$ & 1.00 & 1 \\
\hline $\mathrm{FL}$ & 28 & $12 \cdot 58$ & 0.97 & 3 \\
\hline LA & 60 & $15 \cdot(03$ & 0.92 & 19 \\
\hline $\mathrm{SH}$ & 275 & 6.43 & 1.50 & 1 \\
\hline $\mathrm{BO}$ & 201 & nd & nd & nd \\
\hline Mean \pm SD & $203 \pm 199$ & $11 \cdot 78 \pm 3 \cdot 17$ & $1 \cdot 12 \pm(0 \cdot 19$ & $2 \cdot 6 \pm 4 \cdot 5$ \\
\hline \multicolumn{5}{|c|}{ Pigment stone bile } \\
\hline TH & 146 & $19 \cdot 4$ & $(0.95$ & 8 \\
\hline WA & 31 & $14 \cdot 60)$ & 0.77 & 21 \\
\hline $\mathrm{DA}$ & 39 & $7 \cdot 33$ & 1.03 & 20 \\
\hline $\mathrm{KA}$ & 229 & nd & nd & nd \\
\hline LE & 149 & $11 \cdot 70$ & 0.77 & 21 \\
\hline $\mathrm{HA}$ & $70)$ & $16 \cdot 35$ & 0.75 & 21 \\
\hline Mean \pm SD & $110 \pm 77$ & $13 \cdot 88 \pm 4 \cdot 60$ & $0.85 \pm(0 \cdot 13$ & $18 \cdot 2 \pm 5 \cdot 7$ \\
\hline \multicolumn{5}{|l|}{ Control bile } \\
\hline $\mathrm{RA}$ & 43 & $16 \cdot 16$ & $0 \cdot 83$ & 21 \\
\hline SI & 116 & 8.86 & 1.05 & 6 \\
\hline MA & 364 & 9.90 & 0.68 & 13 \\
\hline AT & 28 & $15 \cdot 85$ & 0.69 & 21 \\
\hline GU & 13 & $10 \cdot 74$ & 0.56 & 21 \\
\hline GR & 34 & 11.92 & 0.66 & 21 \\
\hline $\mathrm{CO}$ & 67 & $11 \cdot 36$ & 0.83 & 21 \\
\hline FR & 53 & nd & nd & nd \\
\hline $\mathrm{PO}$ & 154 & 6.53 & 0.82 & 21 \\
\hline WI & 88 & $14 \cdot 37$ & $1 \cdot 17$ & 1 \\
\hline $\mathrm{PR}$ & 101 & $15 \cdot 24$ & $1 \cdot 30$ & 2 \\
\hline Mean $\pm S D$ & $96 \pm 98$ & $12 \cdot 09 \pm 3 \cdot 24$ & $(0 \cdot 86 \pm 0 \cdot 24$ & $14 \cdot 8 \pm 8 \cdot 6$ \\
\hline
\end{tabular}

quantities of sialic acid were detected in all mucus glycoprotein preparations. No mannose could be detected in any preparation indicating that serum glycoprotein contamination has not interfered with the analysis.

Amino acid analysis of human biliary mucus glycoprotein revealed that threonine, serine, and proline which are characteristically high in mucus glycoproteins constituted $43 \%$ by weight of the protein content. Amino acid analysis also confirmed previous reports ${ }^{24}$ that gall bladder mucus glycoprotein is relatively rich in the acidic amino acids, aspartic and glutamic acids, as well as in glycine and alanine. Relatively little of the basic and aromatic amino acids could be detected.

Carbohydrate and amino acid analyses were done in four patients with cholesterol gall stones and three controls (Table 2). There were no significant differences in constituent carbohydrates. The large mean difference in sialic acid was because of a single high value in a control patient. The amino acid pattern in the control and cholesterol gall stone patients was also quite similar. The mean results of analysis in two patients with obstructed gall bladders and cholesterol gall stones and two patients with pigment stones are also given. 
Table 2 Carbohydrate and amino acid analyses of human bile mucus glycoproteins (mol/100 mol)

\begin{tabular}{|c|c|c|c|c|}
\hline & Normal (3)* & $\begin{array}{l}\text { Cholesterol } \\
\text { stone (4) }\end{array}$ & $\begin{array}{l}\text { White } \\
\text { bile (2) }\end{array}$ & Pigmented (2) \\
\hline \multicolumn{5}{|l|}{ Sugar } \\
\hline Fucose & $9 \cdot 1 \pm 3 \cdot 9^{\prime}$ & $5 \cdot 2 \pm 4 \cdot 2$ & $2 \cdot 8$ & $8 \cdot 3$ \\
\hline Galactose & $30 \cdot 4 \pm 2 \cdot 0$ & $35 \cdot 1 \pm 2 \cdot 6$ & $33 \cdot 8$ & $40 \cdot 3$ \\
\hline $\mathrm{N}-\mathrm{Ac}-$ Galactosamine & $8 \cdot 9 \pm 3 \cdot 8$ & $9 \cdot 4 \pm 0 \cdot 8$ & $10 \cdot 0$ & $4 \cdot 0$ \\
\hline N-Ac-Glucosamine & $37 \cdot 1 \pm 7 \cdot 5$ & $46 \cdot 0 \pm 5 \cdot 7$ & $47 \cdot 7$ & $44 \cdot 3$ \\
\hline Sialic acid & $14 \cdot 6 \pm 14 \cdot 9$ & $4 \cdot 4 \pm 0 \cdot 2$ & $5 \cdot 8$ & $6 \cdot 3$ \\
\hline \multicolumn{5}{|l|}{ Amino acids } \\
\hline Asp & $4.4 \pm 0 \cdot 9$ & $8 \cdot 1 \pm 1 \cdot 0$ & $6 \cdot 6$ & $4 \cdot 3$ \\
\hline Thr & $13 \cdot 8 \pm 3 \cdot 0$ & $13 \cdot 4 \pm 2 \cdot 9$ & $18 \cdot 9$ & $18 \cdot 7$ \\
\hline Ser & $10 \cdot 5 \pm 1 \cdot 3$ & $12 \cdot 9 \pm 2 \cdot 1$ & $11 \cdot 3$ & $10 \cdot 9$ \\
\hline Glu & $8 \cdot 5 \pm 1 \cdot 2$ & $9 \cdot 7 \pm 1 \cdot 2$ & $9 \cdot 2$ & $7 \cdot 9$ \\
\hline Gly & $14 \cdot 2 \pm 5 \cdot 1$ & $15 \cdot 4 \pm 4 \cdot 6$ & $11 \cdot 2$ & $12 \cdot 6$ \\
\hline Ala & $7 \cdot 9 \pm 2 \cdot 4$ & $11 \cdot 4 \pm 2 \cdot 7$ & $10 \cdot 6$ & $8 \cdot 7$ \\
\hline Val & - $^{\mathrm{s}}$ & - & - & - \\
\hline Cys & - & - & - & - \\
\hline Met & - & - & - & - \\
\hline Ile & - & $1.9^{\| \prime}$ & $2 \cdot 2$ & - \\
\hline Leu & $9 \cdot 8 \pm 4 \cdot 6$ & $6 \cdot 1 \pm 4 \cdot 6$ & $7 \cdot 6$ & $7 \cdot 5$ \\
\hline Tyr & - & - & 1.7 & - \\
\hline Phe & $1 \cdot 8 \pm 0.9$ & $3 \cdot 3 \pm 1 \cdot 0$ & $3 \cdot 1$ & $1 \cdot 1$ \\
\hline His & $2 \cdot 8 \pm 0 \cdot 8$ & $2 \cdot 9 \pm 1 \cdot 1$ & $3 \cdot 0$ & $3 \cdot 7$ \\
\hline Lys & $3 \cdot 0 \pm 0 \cdot 6$ & $3 \cdot 2 \pm 1 \cdot 2$ & $3 \cdot 1$ & $2 \cdot 4$ \\
\hline Arg & $2 \cdot 6 \pm 0 \cdot 2$ & $1.9 \pm 1 \cdot 3$ & $2 \cdot 4$ & 1.4 \\
\hline Pro & $20 \cdot 7 \pm 1.9$ & $10 \cdot 5 \pm 7 \cdot()$ & $10 \cdot 7$ & $21 \cdot 0$ \\
\hline
\end{tabular}

Number of patients in each group.

Mcan \pm SD

$\left.{ }^{+} \mathrm{p}<0\right) \cdot 05$ when compared with cholesterol gall stone values (Student's $t$ test).

${ }^{\mathrm{s}}$ Not detected or less than $1 \%$.

"Detected in two samples only.

\section{Discussion}

QUANTITATIVE ANALYSIS

Gall bladder mucus glycoprotein concentrations have been determined indirectly by assay of hexosamine content. ${ }^{7} 1718$ The results have been conflicting. Indirect determination by hexosamine content may lead to uncertainties because of the presence of other glycoproteins containing hexosamines such as plasma glycoproteins. Erroneous results may also occur owing to incomplete removal of monosaccharides from bile or by incomplete hydrolysis of mucus to hexosamines before analysis. Direct measurement of undegraded native mucin is a more reliable measurement.

Pearson et $a l^{24}$ recently described methods for isolation of mucus glycoprotein from other biliary constitutents, particularly pigment. This represented a certain advance as it permitted direct analysis of mucus glycoprotein concentrations. They measured concentrations of mucus glycoprotein in gall bladder bile of three patients with mixed type cholesterol gall stones and found concentrations to be $200-500 \mu \mathrm{g} / \mathrm{ml}$. In the present study, we have used the methods of Pearson et al to isolate and quantify mucus glycoprotein concentrations in several patient groups.

No difference between mucus glycoprotein concentrations among patient groups with functioning gall bladders was found. Nor was there any correlation between nucleation time and mucus glycoprotein concentration. This indicates that an increased concentration of mucus glycoprotein in bile is not responsible for the characteristic rapid nucleation time found in cholesterol gall stone patients in vitro. Although unlikely, the possibility exists that the onset of nucleation in vivo may be associated with a temporary increase in glycoprotein concentration which then returns to normal levels once nucleation has occurred.

A few patients with cholesterol gall stones did have high concentrations of mucus glycoprotein. This may have been due to partial obstruction of the cystic duct, a response to inflammation or these patients may represent a small subpopulation in which mucus glycoprotein concentrations in bile are truly raised. Obstruction of the gall bladder results in an approximate 10-fold increase in mucus glycoprotein concentrations, as seen in the white bile group. This had been reported previously, ${ }^{36}$ and 
white bile provides an excellent source of gall bladder mucus glycoprotein.

QUALITATIVE ANALYSIS

A change in mucus glycoprotein composition has been suggested in inflammatory bowel disease ${ }^{37}$ and it seemed possible that a qualitative alteration of mucus glycoprotein might explain nucleation time differences in patients with and without gall stones.

Previous qualitative investigations had been limited to animal models, ${ }^{13} 38$ patients with functional liver disturbances, ${ }^{19}$ or gall bladder bile obtained at necropsy. ${ }^{20} 22$ Isolation procedures usually used harsh extraction procedures and proteolytic digestion or failed to remove contaminating material. Some studies have also limited their analysis to only the carbohydrate component of the mucus glycoprotein. ${ }^{1319} 22$ Other studies have used hepatic bile obtained by T-tube drainage ${ }^{1921}$ as their source of mucus glycoprotein. Therefore, direct comparison of the qualitative analysis of mucus glycoprotein with earlier studies are difficult.

In general, the carbohydrate composition of our biliary mucus is compatible with previous preparations of biliary glycoprotein. ${ }^{20-22} 24$ Our data can probably be compared with that of Pearson et al because the isolation methods were the same. There was less fucose and more glucosamine in our preparations. Pearson and colleagues found proportionately more galactosamine and less glucosamine in the mucus glycoproteins isolated from a blood group A individual. Schrager et $a l^{20}$ also found proportionately more galactosamine in the biliary mucus associated with blood group $\mathrm{A}$ and increased galactose residues associated with blood group B. Individual blood group type was not obtained in the present study and could account for the differences.

The amino acid analyses in this study are generally quite similar to those reported by Pearson et $a l^{24}$ with the major entities being threonine, serine, and proline. These amino acids constituted about $43 \%$ by weight of the protein content compared with $39 \%$ by Pearson et al.

There were no significant differences in carbohydrate composition between patients with cholesterol gall stones and control patients. The amino acid composition in the two groups was also very similar although there was a significant difference in per cent aspartic acid. The significance of this finding must be interpreted with caution because of the small sample size. Our qualitative analysis has given only 'crude' compositional data of mucus glycoprotein in patients with and without gall stones. Obviously glycoproteins whose amino acid and carbohydrate sequences are very different can contain similar amino acid and carbohydrate compositions. Our qualitative analysis of mucus glycoprotein has not included sulphate groups. Gall bladder mucins are sulphated and a change in the sulphate content might be important. ${ }^{919}$ Whether structurally different mucus glycoproteins exist in patients with cholesterol gall stones remains to be determined. Functional studies may determine whether this is so. Levy et al have reported that mucus glycoprotein from stone patients increases the number of cholesterol crystals nucleating from model biles. Control mucus glycoprotein isolated from cadaver bile had a lesser effect. ${ }^{16}$ We have been unable to substantiate this difference using mucus glycoprotein obtained at surgery from control and cholesterol gall stone patients using nucleation time as the end point. ${ }^{39}$ Furthermore, complete removal of mucus glycoprotein from bile does not slow nucleation time of abnormal bile. ${ }^{39}$

A few samples of pigment stone bile and white bile from cholesterol gall stone patients were available for analysis. The results indicate that there are probably no major differences in composition from controls in these groups.

This study was supported by the Medical Research Council of Canada, and the Physicians Services Incorporated Foundation.

\section{References}

1 Admirand WH, Small DM. The physicochemical basis of cholesterol gallstone formation in man. J Clin Invest 1968; 47: 1043-52.

2 Carey MC, Small DM. The physical chemistry of cholesterol solubility in bile: relationship to gallstone formation and dissolution in man. J Clin Invest 1978; 61: 998-1026.

3 Holan KR, Holzbach RT, Hermann RE, Cooperman AM. Claffey WJ. Nucleation time: a key factor in the pathogenesis of cholesterol gallstone disease. Gastroenterology 1979; 77: 611-17.

4 Sedaghat A, Grundy SM. Cholesterol crystals and the formation of cholesterol gallstones. N Engl J Med 1980; 302: 1274-6.

5 Gollish SH, Burnstein MJ, Ilson RG, Petrunka CN, Strasberg SM. Nucleation of cholesterol monohydrate crystals from hepatic and gallbladder bile of patients with cholesterol gallstones. Gut 1983; 24: 836-44.

6 Burnstein MJ, Ilson RG, Petrunka CN, Taylor RD, Strasberg SM. Evidence for a potent nucleating factor in the gallbladder bile of patients with cholesterol gallstones. Gastroenterology 1983; 85: 801-7.

7 Whiting MJ, Watts J McK. Supersaturated bile from obese patients without gallstones supports cholesterol crystal growth but not nucleation. Gastroenterology 1984; 86: 243-8.

8 Womack NA, Zeppa R, Irvin GL. Anatomy of gallstones. Ann Surg 1963; 137: 670-86. 
9 Maki T, Matsushiro T, Suzuki N, Nakamura N. Role of sulfated glycoprotein in gallstone formation. Surg Gynecol Obstet 1971; 132: 846-54.

10 Nakamura N. Mucopolysaccharides and their significance in gallstone formation. Tohoku J Exp Med 1967; 93: $235-47$.

11 Womack NA. The development of gallstones. Surg Gynecol Obstet 1971; 133: 937-45.

12 Freston JW, Bouchier IAD, Newman J. Biliary mucous substances in dihydrocholesterol-induced cholelithiasis. Gastroenterology 1969; 57: 670-8

13 Lee SP. Hypersecretion of mucous glycoprotein by the gallbladder epithelium in experimental cholelithiasis. $J$ Pathol 1981; 134: 199-207.

14 Lee SP, LaMont JT, Carey MC. Role of gallbladder mucus hypersecretion in the evolution of cholesterol gallstones. J Clin Invest 1981; 67: 1712-23.

15 Lee SP, Carey MC, LaMont JT. Aspirin prevention of cholesterol gallstone formation in prairie dogs. Science 1981; 211: 1429-31.

16 Levy PF, Smith BF, LaMont JT. Human gallbladder mucin accelerates nucleation of cholesterol in artificial bile. Gastroenterology 1984; 87: 270-5.

17 Giles RB, Smith JE, Crowley G, Michael M. A study of carbohydrates in human gall bladder bile. J Lab Clin Med 1960; 55: 38-45.

18 Bouchier IAD, Cooperband SR, El Kodsi BM. Mucous substances and viscosity of normal and pathological human bile. Gastroenterology 1965; 49: 343-53.

19 Matsushiro $T$, Nemoto $T$, Endo $M$, Yosizawa $Z$. Glycoproteins and sulfated glycoproteins isolated from human bile. Clin Chim Acta 1970; 30: 645-55.

20 Schrager J, Oates MDG, Rosbottom A. The isolation and partial characterization of the principal biliary glycoprotein. Digestion 1972; 6: 338-55.

21 Bouchier IAD, Clamp JR. Glycoproteins in human bile. Clin Chim Acta 1971; 35: 219-24.

22 Lee SP, Lim TH, Scott AJ. Carbohydrate moieties of glycoproteins in human hepatic and gallbladder bile, gall-bladder mucosa and gall stones. Clin Sci 1979; 56: 533-8.

23 Starkey BJ, Snary D, Allen A. Characterization of gastric mucoproteins isolated by equilibrium densitygradient centrifugation in caesium chloride. Biochem $J$ 1974; 141: 633-9.

24 Pearson JP, Kaura R, Taylor W, Allen A. The composition and polymeric structure of mucus glyco- protein from human gallbladder bile. Biochim Biophys Acta 1982; 706: 211-28.

25 Morin RJ, Elms NJ. Rapid microanalysis of cholesterol in bile and serum by gas chromatography. Ann Clin Lab Sci 1975; 5: 52-6.

26 Bradford MM. A rapid and sensitive method for the quantitation of microgram quantities of protein utilizing the principle of protein dye binding. Anal Biochem 1976; 72: 248-54.

27 Mantle M, Allen A. A colorimetric assay for glycoprotein based on the periodic acid/Schiff stain. Biochem Soc Trans 1978; 6: 607-9.

28 Laemmli UK. Cleavage of structural proteins during the assembly of the head of bacteriophage T4. Nature 1970; 227: 680-5.

29 Glossmann H, Neville DM. Glycoproteins of cell surfaces. A comparative study of three different cell surfaces of the rat. $J$ Biol Chem 1971; 246: 6339-46.

30 Merril CR, Goldman D, Sedman SA, Ebert MH. Ultrasensitive stain for proteins in polyacrylamide gels shows regional variation in cerebrospinal fluid proteins. Science 1981; 211: 1437-8.

31 Bartlett GR. Phosphorous assay in column chromatography. J Biol Chem 1959; 234: 466-8.

32 Talalay P. Enzymic analysis of steroid hormones. Methods Biochem Anal 1960; 8: 119-45.

33 Carey MC. Critical tables for calculating the cholesterol saturation of native bile. J Lipid Res 1978; 19: $945-55$.

34 Laine RA, Esselman WJ, Sweeley CC. Gas liquid chromatography of carbohydrates. Methods Enzymol 1972; 28: 159-67.

35 Clamp JR. Mucus in health and disease. In: Elstein M, Parke DV, eds. Mucus in health and disease. New York: Plenum Press, 1977: 1-15.

36 Bouchier IAD, Cooperband SR. The characteristics of "white bile". Gastroenterology 1965; 49: 354-9.

37 Podolsky DK, Isselbacher KJ. Composition of human colonic mucin-selective alteration in inflammatory bowel disease. J Clin Invest 1983; 72: 142-53.

38 Neiderhiser DH, Plantner JJ, Carlson DM. The purification and properties of the glycoproteins of pig gallbladder bile. Arch Biochem Biophys 1971; 145: 155-63.

39 Gallinger S, Harvey PRC, Petrunka CN, Strasberg SM. The effect of mucous glycoprotein on nucleation time of human bile. Gastroenterology 1985; 89: 648-58. 